\title{
Article \\ Critical Evaluation of Two Commercial Biocontrol Agents for Their Efficacy against B. cinerea under In Vitro and In Vivo Conditions in Relation to Different Abiotic Factors
}

\author{
Gurkan Tut $^{1,2}$, Naresh Magan ${ }^{2, *(D)}$, Philp Brain ${ }^{1}$ and Xiangming $X u^{1, *(D)}$ \\ 1 NIAB East Malling Research, West Malling, Kent ME19 6BJ, UK; Gurkan.Tut@hotmail.com (G.T.); \\ Philip.Brain@NIAB.com (P.B.) \\ 2 Applied Mycology Group, Environment and AgriFood Theme, Cranfield University, Cranfield, \\ Bedford MK43 0AL, UK \\ * Correspondence: n.magan@cranfield.ac.uk (N.M.); Xiangming.Xu@niab.com (X.X.); \\ Tel.: +44-1234-758308 (N.M.)
}

Citation: Tut, G.; Magan, N.; Brain, P.; Xu, X. Critical Evaluation of Two Commercial Biocontrol Agents for Their Efficacy against B. cinerea under In Vitro and In Vivo Conditions in Relation to Different Abiotic Factors. Agronomy 2021, 11, 1868. https:// doi.org/10.3390/agronomy11091868

Academic Editor: Eligio Malusá

Received: 24 August 2021

Accepted: 13 September 2021

Published: 17 September 2021

Publisher's Note: MDPI stays neutral with regard to jurisdictional claims in published maps and institutional affiliations.

Copyright: (c) 2021 by the authors. Licensee MDPI, Basel, Switzerland. This article is an open access article distributed under the terms and conditions of the Creative Commons Attribution (CC BY) license (https:// creativecommons.org/licenses/by/ $4.0 /)$.

\begin{abstract}
The study evaluated the dose-response relationship of two commercial microbial biocontrol agents, Bacillus subtilis and Gliocladium catenulatum, against Botrytis cinerea both in vitro and in vivo. Inoculum doses, formulation, temperature and foliar leaf part all affected the control achieved by the two BCAs. In vitro competition assays on modified PDA plates tested a range of BCA doses ( $\log _{10} 3-10$ CFUs or spores/droplet) at 4,10 and $20^{\circ} \mathrm{C}$ on the development of $B$. cinerea colonies. The dose-response relationship was influenced by both the BCA formulation and temperature. In vivo studies on lettuce plants in semi-commercial greenhouses examined the BCA dose $\left(\log _{10} 5-9\right.$ CFUs or spores $/ \mathrm{mL}$ ) for controlling $B$. cinerea with a high inoculum $\left(\log _{10} 6\right.$ spores $\left./ \mathrm{mL}\right)$. Leaf disc assays showed that the dose-response relationship was influenced by the leaf parts sampled. These results suggest that the dose-response relationship between a BCA and specific pathogen will be significantly influenced by environmental conditions, formulation and plant phyllosplane tissue.
\end{abstract}

Keywords: commercial biocontrol agents; formulation; temperature; Botrytis cinerea; Bacillus subtilis; Gliocladium catenulatum; biocontrol; dose-response; spatial effects

\section{Introduction}

Bacillus subtilis, a Gram-positive Rhizobacterium produces endospores for survival and lipo-peptides (iturins, fengycins, surfactins) for plant colonization, induction of plant defense responses and control of plant pathogens [1]. The ability of $B$. subtilis to compete for space and nutrients is important for the survival and colonization of plants [2]. Serenade $\mathrm{ASO}^{\circledR}$ (Bayer Crop Science), a globally used broad spectrum bio-fungicide, contains B. subtilis strain QST 713 and is registered in Europe to manage Botrytis cinerea on crops, including lettuce and strawberry [3]. Gliocladium catenulatum, a saprophytic filamentous fungus, survives on organic matter and as an endophyte in roots and stems, is rhizosphere-competent and reportedly competitive against a range of fungal plant pathogens [4]. G. catenulatum, which has also been suggested to be parasitic to fungal pathogens [5], destroying hyphal cells [6], produces enzymes (chitinase, $\beta$-1,3-glucanases) for the hydrolysis of fungal cell walls [7] and is effective at competing for space and nutrients in plants [8]. Prestop ${ }^{\circledR}$ (ICl Ltd., Ipswich, Suffolk, UK), broad-spectrum bio-fungicide, contains conidia and mycelium of G. catenulatum strain J1446 and is registered in Europe to manage B. cinerea on crops.

$B$. cinerea is an economically important pathogen of lettuce. Under conducive conditions, conidia infects the base of the plant and the disease develops upwards throughout the head until all inner leaves are altered into a slimy mass $[9,10]$. The pathogen rots the stem and leaves at the center before reaching the margin of the outer leaves. Characteristic ashen-grey lesions form with conidial sporulation just above the surface of the diseased 
area. They are often on the underside of the leaves where the moist microclimate is better. Subsequently, sclerotia develop throughout the decayed leaves $[9,10]$.

Serenade $\mathrm{ASO}^{\circledR}$ is a suspension concentrate containing of Bacillus amyloliquefaciens (=subtilis) strain of QST 713 (including fermentation residues and water with a minimum of $1.05 \times 10^{12}$ CFUs/L. PRESTOP ${ }^{\circledR}$ is a biofungicide consisting of a $32 \% w / w$ wettable powder containing a nominal $2 \times 10^{8} \mathrm{CFUs} / \mathrm{g}$ and applied at the rate of $500 \mathrm{~g}$ per $100 \mathrm{~L}$ $(0.5 \%)$. For these foliar applications, a better understanding of the BCA-pathogen dose relationships are needed before such bio-fungicides can be effectively exploited to manage more generally plant diseases in commercial agriculture and horticulture.

Generally, dose-response relationships are often characterised by probit models. For determining timing of BCA applications, considerations include pathogen infection risks, ensuring viable biocontrol population sizes and the $\mathrm{BCA} /$ pathogen dose relationship under specific environmental conditions [11]. Surprisingly, there has been no published information on the dose-response model relationships for B. subtilis and G. catenulatum against $B$. cinerea. These models would be very valuable to obtain information on the effective dose required for reduction of the pathogen population by $50 \%\left(\mathrm{LD}_{50}\right)$. In addition, the efficacies will be influenced by both biotic and abiotic factors, including the formulation and target host tissue. Thus, intra-leaf positions and target leaf parts are a critical step in understanding the ecology of the BCA and pathogen. Such information would enable a more targeted approach to maximise the application timing and targeting, especially of phylloplane surfaces, to optimise biocontrol efficacy [12].

The objective of the present research was to evaluate the dose-response relationships of these two BCAs (B. subtilis QST 713, G. catenulatum J1446) against the pathogen B. cinerea (a) in vitro and (b) in-situ in relation to temperature and BCA formulation, as well as biotic spatial effects in the phylloplane of lettuce leaves.

\section{Materials and Methods}

2.1. Isolation and Culture Conditions of B. subtilis QST 713, G. catenulatum J1446 and B. cinerea

Serenade ${ }^{\circledR}$ ASO (Serenade) and Prestop were purchased from Fargro Ltd (Arundel, West Sussex, UK). Serenade was an aqueous formulation and contained B. subtilis strain QST 713. Prestop ${ }^{\circledR}$ was a dry formulation and contained G. catenulatum strain J1446. For both bio-fungicides, culture conditions, growth and formulation components were unknown due to industrial proprietary. Serenade was stored at room temperature, while Prestop was stored in a cool dry location at $<8^{\circ} \mathrm{C}$ and, once opened, frozen at $-20^{\circ} \mathrm{C}$. The batches used were less than 6 months old. It should be noted that up to $\log _{10} 1 \mathrm{CFUs}$ or conidia / $\mathrm{mL}$ were found to be non-viable in the formulations when counted in a haemocytometer and plated on agar media. Each BCA was isolated from their formulations and grown in vitro on culture media. Serenade was serially diluted thrice into maximum recovery diluent (Sigma Aldrich, Gillinham, Dorset, UK) and $10 \mu \mathrm{L}$ was spread-plated onto nutrient agar (NA, Oxoid Ltd) and incubated at $30^{\circ} \mathrm{C}$ for three days. Concentrates were produced by collecting the bacterial colonies on the media into maximum recovery diluent solution and transferring the supernatant (B. subtilis suspended into maximum recovery diluent) onto the next plate to repeat the process. The concentrate was stored at $20{ }^{\circ} \mathrm{C}$. One gram of Prestop was mixed with $200 \mathrm{~mL}$ of maximum recovery diluent, shaken vigorously for $15 \mathrm{~s}$ and serially diluted twice, before $10 \mu \mathrm{L}$ were plated. Then, the mixture was spread-plated on malt extract agar (MEA, Oxoid Ltd) and incubated at $22{ }^{\circ} \mathrm{C}$ for 10 days. Concentrates were produced by collecting the surface fungal growth into maximum recovery diluent solution and transferring the supernatant ( $G$. catenulatum suspended into maximum recovery diluent) to the next plate and repeating the process. The hyphae and mycelia were separated from the macroconidia in the suspension by filtration (Whatman $25 \mu \mathrm{m}$ ).

For in vitro dual culture assays, three single-spored B. cinerea strains were isolated from separate strawberry fruits (cultivar Elsanta) with grey mould symptoms at a strawberry production facility at East Malling and plated on potato dextrose agar (PDA, Oxoid 
Ltd), followed by incubation at $20^{\circ} \mathrm{C}$ for 10 days in the dark. These isolates were used because these studies were performed out of lettuce production season. The fungal colonies from each plate were placed into the same sterile beaker, mixed with maximum recovery diluent solution and stored at $4{ }^{\circ} \mathrm{C}$. From the mixed isolate suspension, $200 \mu \mathrm{L}$ was spreadplated onto PDA, followed by incubation at $20^{\circ} \mathrm{C}$ for 10 days in the dark. For in planta experiments, four isolates of $B$. cinerea were obtained directly from lettuce leaves (cvs. Cos Romia, Little Gem, Lollo Verdi and Apolo) infected with B. cinerea from a commercial lettuce field in West Malling, Kent and three further B. cinerea isolates were collected from lettuce (cv. Carter) infected with the pathogen from a semi-commercial glasshouse at NIAB EMR. The collected isolates were cultured on PDA and incubated at $20^{\circ} \mathrm{C}$ for 10 days with $8 \mathrm{~h}$ light $/ 16 \mathrm{~h}$ dark cycles. For acquiring conidia from the $B$. cinerea cultures, $10 \mathrm{~mL}$ of sterile distilled water was added to the colony surface and the culture agitated for conidial release. Supernatants were collected, filtered (Whatman $25 \mu \mathrm{m}$ ), serially diluted and confirmed with microscopic counts using a haemocytometer, to contain macro-conidial concentrations of about $1 \times 10^{6}$ spores $/ \mathrm{mL}$. The in vitro experiment used a mixture of all three isolates from Carter, while the in-planta experiment used a mixture of all the lettuce isolates combined as a mixed pathogen $B$. cinerea inoculum.

\subsection{In Vitro Dual Culture Co-Inoculations}

The viable plate count technique was used to confirm BCA dosage (B. subtilis, G. catenulatum). For Serenade (B. subtilis), assays were performed on mixed media consisting of $50 \%$ of the recommended PDA and NA agars, while for Prestop (G. catenulatum), assays were performed on $50 \%$ of recommended PDA and $50 \%$ of the MEA. For non-formulated strains, the concentrations used were between $5 \times 10^{3}$ and $5 \times 10^{9}$ (at an increment of one order of magnitude) CFUs for B. subtilis and spores for G. catenulatum per droplet. For the two formulated products, eight inoculum doses were tested, ranging from $5 \times 10^{3}$ to $5 \times 10^{10}$ (at an increment of one order of magnitude) per droplet in the formulated product.

Testing was carried out in single vent $90 \mathrm{~mm} \times 16.2 \mathrm{~mm}$ Petri plates. A modified dual culture technique [13] was used, in which an agar plug of $34 \mathrm{~mm}$ in diameter was removed with a surface sterilised cork borer and then re-plugged with a mycelial plug of the same size containing both the agar and the B. cinerea fungal layer. In succession the BCA droplet was applied. The plug site of the pathogen and the application site of the BCA droplet in the Petri plate were opposite each other, $6.5 \mathrm{~cm}$ apart and $1 \mathrm{~cm}$ from the edge of the plate. The plates were sealed with parafilm and incubated at 4,10 or $20^{\circ} \mathrm{C}$ for 7 days in the dark. The positive control contained the B. cinerea mycelial plug only and the negative control contained no microorganisms. After 7 days, images of dual cultures and positive controls were obtained and analysed with ImageJ (National Institutes of Health, Bethesda, $\mathrm{MD}, \mathrm{USA})$ to calculate the $B$. cinerea mycelial area colonised. Each treatment $(\mathrm{BCA} \times$ dose $\times$ temperature) contained a maximum of thirty and a minimum of nine replicates, these replicates were broken down into three independent experiments using a randomised block design.

\subsection{Effect of the Two BCAs on Control of B. cinerea on Lettuce Leaves}

Lettuce cultivar Carter was grown in pots $(9 \times 9 \times 10 \mathrm{~cm})$ with Miracle-Gro All Purpose Premium Compost (Evergreen Garden Care Ltd., Frimley, Surrey, UK) and placed in a semi-commercial pest- and disease-free glasshouse until early head development with about 4- 6 bottom leaves. During experimentation, lettuce plants were hand watered daily and the glasshouse temperature and relative humidity ranged between 17 and $22{ }^{\circ} \mathrm{C}$ and $60 \%$ and $95 \%$, respectively.

The viable plate count technique was used to confirm the BCA dosage. At the point of early head development, the lettuce plants were spray-inoculated with a hand sprayer in fine droplets and sprayed until just before run-off with the individual BCA or with sterile distilled water for the negative and positive controls. Five doses tested were $5 \times 10^{5}$, $5 \times 10^{6}, 5 \times 10^{7}, 5 \times 10^{8}$ and $5 \times 10^{9} \mathrm{CFU} / \mathrm{mL}$ for Serenade and spores/mL for Prestop. 
Four hours after the BCA application, plants were similarly spray inoculated with $B$. cinerea (macro-conidial dosage of $1 \times 10^{6}$ spores $/ \mathrm{mL}$ ), except for the negative control which was sprayed with sterile distilled water. For $48 \mathrm{~h}$, the glasshouse ventilation windows were closed to encourage infection and after $48 \mathrm{~h}$, two older leaves from each plant (defined by their larger size and marked with a permanent marker at the time of inoculation) of similar size and shape were collected and surface sterilized. Phylloplane leaf surface washing consisted of initially using slow running cold tap water, followed by a 1 min wash in tween 80 solution (1 drop in $200 \mathrm{~mL}$ sterile distilled water), re-washed with sterile distilled water twice, then surface sterilized with a wash in $70 \%$ ethanol for $1 \mathrm{~min}$. The residual alcohol was removed by washing twice in sterile distilled water, followed by leaf drying under a fume hood for $2 \mathrm{~h}$. From each older lettuce leaf, a total of ten leaf discs (10 mm diameter) were obtained and leaf parts included the apex (1 disc), midrib (3 discs) and lamina with lateral veins (6 discs). Figure 1 illustrates the relative positions of the 10 sampled leaf disc on each leaf. The discs were placed on PDA at an equal distance from each other $(0.75 \mathrm{~cm})$, the plate was sealed with parafilm and incubated at $20^{\circ} \mathrm{C}$ for 10 days in the dark. After the incubation period, the leaf discs were assessed for the incidence of disease and/or symptoms (i.e., lesions, hyphae and necrosis). The experiment was performed twice. In each experiment for each treatment $(\mathrm{BCA} \times$ dose), there were five biological replicates (five plants), and from each plant two of the oldest leaves were obtained for experimentation (two replicates). Therefore, each treatment dose contained a total of twenty leaves. The testing followed a randomised block design.

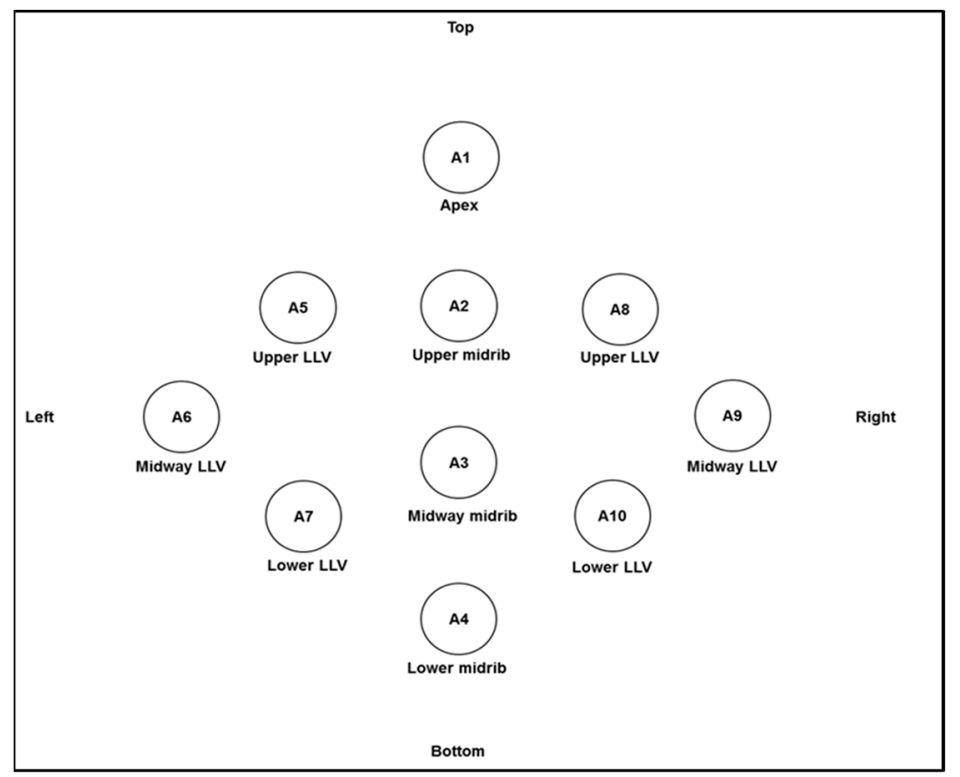

Figure 1. Diagrammatic representation of leaf disc positions taken from older L. sativa leaves (This is not to scale. Key: LLV, lamina and lateral veins.

\subsection{Data Analyses}

Generalised linear models (GLM) were used to analyse the dose-response relationship, assuming residual errors to follow a binomial distribution. For in vitro dual culture data, biocontrol efficacy (E) was calculated as:

$$
E=[(C-T) / C] \times 100
$$

where $C$ and $T$ was the area of $B$. cinerea mycelial colonisation of the agar plate for the control and treatment, respectively. In GLM analysis of the efficacy data for each BCA, formulation (formulated or not) and temperature $\left(4,10\right.$ and $20^{\circ} \mathrm{C}$ ) were treated as factors. Any E values less than 0 were set to 0 , and similarly those values greater than 100 were set 
to 100. In GLM analysis of the efficacy (E) data, the total counts for individual data points was assumed to be 100 .

For the leaf disc data, GLM was applied to the data at two levels. At the first level, data were pooled over all leaf disc positions from the two repeat experiments. Percent leaf discs infected for each combination of BCA and dose was first adjusted for the level of latent (pre-existing) infection of $B$. cinerea (as in the negative control (NC)) and the maximum level of infection (as in the positive control (PC)), namely:

$$
\text { Iadj }=(\mathrm{I}-\mathrm{INC}) /(\mathrm{IPC}-\mathrm{INC}) * 100
$$

where I and Iadj are respectively observed and adjusted percent infection for a treatment, and IPC and INC are observed percent infection for the NC and PC treatments, respectively. In GLM analysis, for each combination of BCA and dose, the total leaf disc was 200 and the number of infected leaf disc was estimated from Iadj. BCA was included in GLM as a factor.

At the second level, GLM was applied to data at individual leaf positions. Percent infection was similarly adjusted for specific leaf locations for each BCA. Any adjusted values less than 0 were set to 0 , and similarly those values greater than 100 were set to 100 . In GLM analysis, for each combination of BCA, leaf position and dose, the total number of leaf discs was 20 and the number of infected discs was estimated from Iadj. Leaf position and BCA were treated as factors in GLM.

For all GLM analyses of the data, an additional data point at zero dose with zero efficacy was added. Accumulated deviance analysis was used to assess the effects of treatment factors on the dose-response relationship. All analyses were carried out in $\mathrm{R}$ (version 4.1.0).

\section{Results}

3.1. Effect of BCA Inoculum Dose, Formulation and Temperature on In Vitro Control of B. cinerea

Figures 2 and 3 show that the relative inhibition of $B$. cinerea mycelial colonisation occurred in all tested temperatures with both the BCAs and was generally increasing with dosage. The highest inoculum doses assayed with Serenade and Prestop resulted in the highest control efficacy of $96 \%$ and $91 \%$, respectively.

For the Bacillus, analysis of accumulated deviance showed that both formulation and temperature affected $(p<0.001)$ the dose-response relationship, affecting both the intercept and slope parameters. Formulated strains retained greater efficacy at each temperature and inoculum dose (Figure 2), particularly for low doses. Indeed, the higher-than-expected efficacies at low doses for the formulated product led to large deviations in model predictions.

Similarly, for the Gliocladium, both temperature and formulation affected $(p<0.001)$ the observed dose-response relationship. The effect of dose was less profound at $10{ }^{\circ} \mathrm{C}$ for the unformulated strain (Figure 3). 


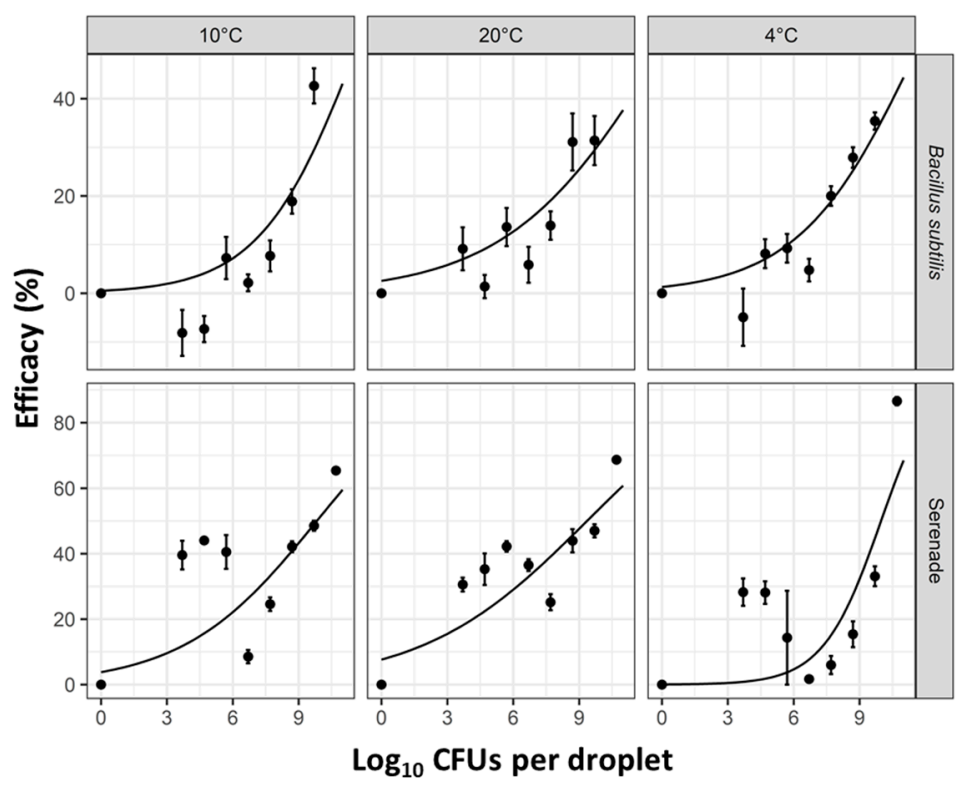

Figure 2. Efficacy from in vitro competition assays of $B$. subtilis and Serenade at tested inoculum doses inhibiting growth from a $B$. cinerea mycelial plug at 4,10 and $20{ }^{\circ} \mathrm{C}$; the bars represent one standard error and the curve is a fitted logistic model.

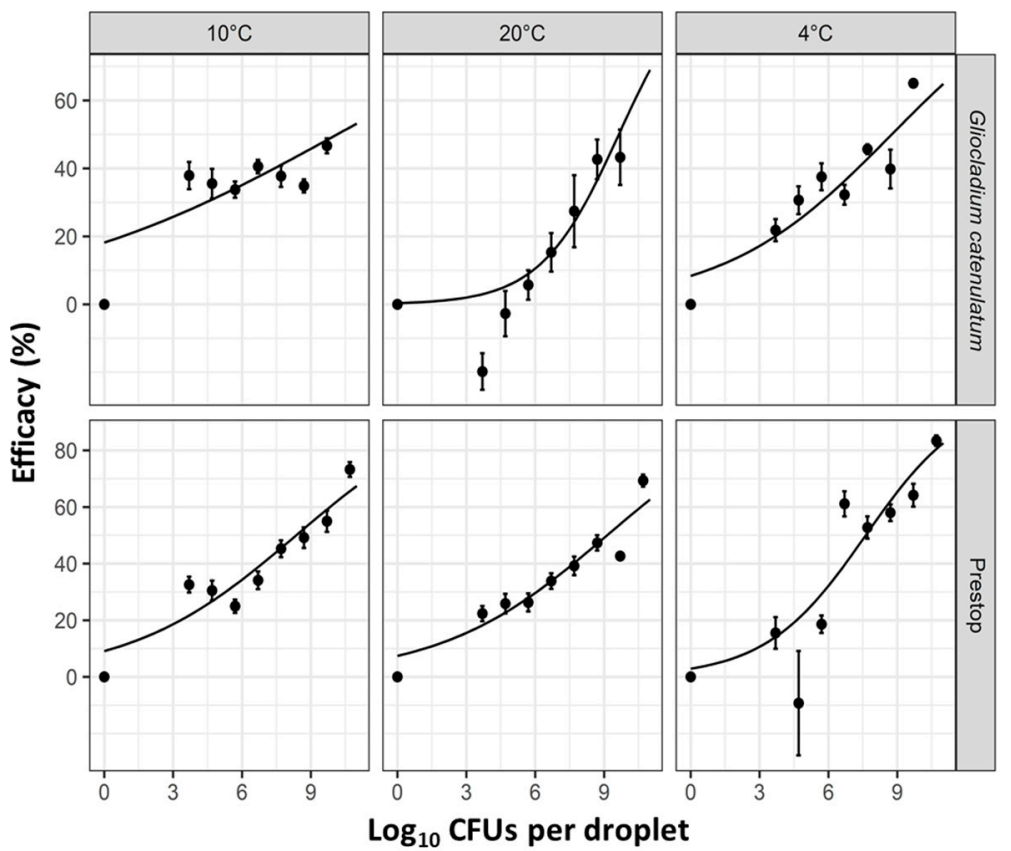

Figure 3. Efficacy from in vitro competition assays of G. catenulatum and Prestop at tested inoculum doses inhibiting growth of a B. cinerea mycelial plug at 4,10 and $20^{\circ} \mathrm{C}$; the bars represent one standard error and the curve is a fitted logistic model.

3.2. In Vivo Dose-Response Relationship and Inoculum Dynamics of the BCAs on Lactuca Sativa Leaves under HIgh B. cinerea Inoculum Pressure

3.2.1. Analysis of the Leaf-Disc Data Ignoring the Spatial Location

Figure 4 shows the incidence of leaf discs infected with $B$. cinerea in relation to the application of Serenade and Prestop at several doses following inoculation with $B$. cinerea. As BCA inoculum dose increased, the infection level decreased. Complete or close to complete control $(100 \%)$ of $B$. cinerea may be achievable with the highest inoculum dose of $\log _{10} 9.7$ CFUs or spores/mL. 


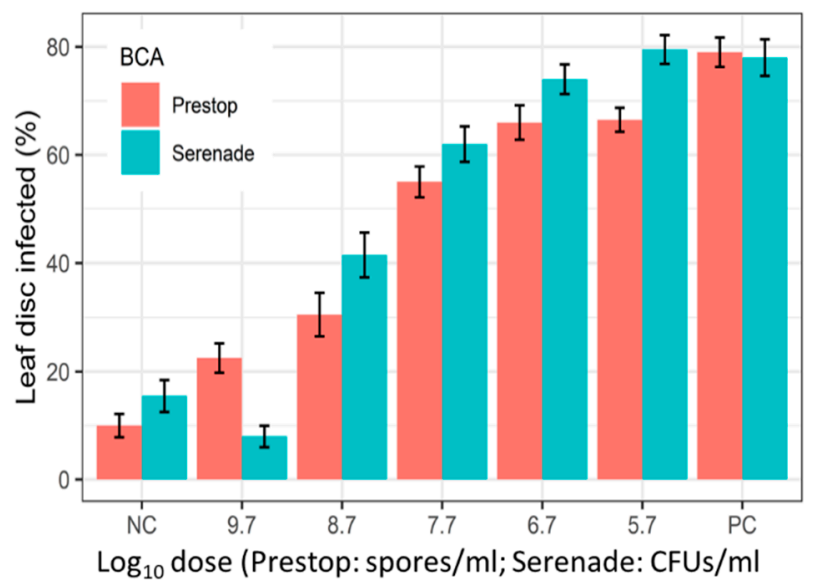

Figure 4. Overall percent $L$. sativa leaf disc infected with B. cinerea when post-inoculation challenged with two formulated biocontrol products (Prestop and Serenade) at a number of doses in a glasshouse at $17-22{ }^{\circ} \mathrm{C}$ with a $\mathrm{RH}$ range of $60-100 \%$. NC: negative control (only sterile water was applied) and PC: positive control (inoculated with B. cinerea but not treated with BCA).

Logistic models satisfactorily described the observed dose-response relationships (Figure 5). The response curve is steeper $(p<0.05)$ for Serenade than for Prestop. However, $\mathrm{LD}_{50}$ for both BCAs were close, at around $\log _{10} 8.0 \mathrm{CFUs}$ or spores/mL (see Figure 5).

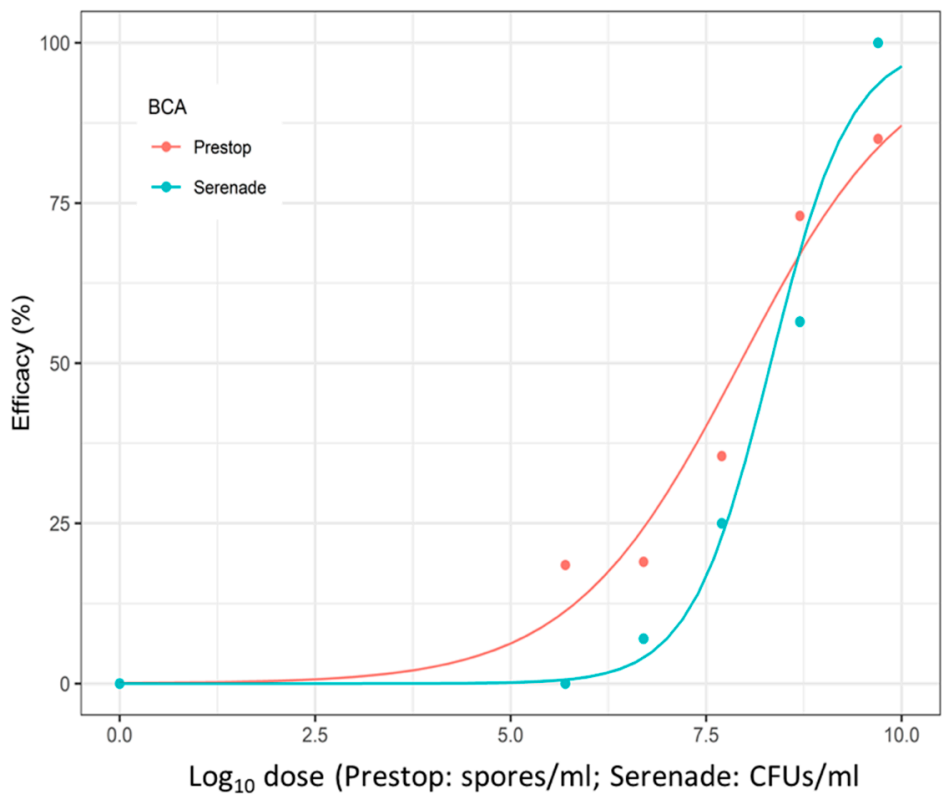

Figure 5. Fitted logistic models describing the dose-response relationship of B. cinerea infection of lettuce leaves in relation to different doses of the two biocontrol (BCA) agents (Prestop and Serenade) examined.

3.2.2. Effect of Spatial Leaf Disc Position on Dose-Response Relationship of the Two BCAs for B. cinerea Control

Analysis of accumulated deviance indicated that both inoculum dose and leaf disc position affected $(p<0.001)$ the control efficacy achieved by two BCAs. These two factors affected both the intercept and slope parameters. Figure 6 shows the observed efficacy data as well as the fitted models for each leaf disc position.

For Prestop, the difference in the dose-response relationship among 10 leaf positions resulted mostly from the fact that positions A4 and A6 differed greatly from other positions, with much lower efficacies achieved (see Figure 6), which was confirmed by the analysis of 
deviance. For Serenade, the dose-response relationship for position A6 differed largely from other positions, with a much steeper response. Only the two highest doses led to disease control (see Figure 6), and the significance of this difference was indicated by the analysis of deviance.

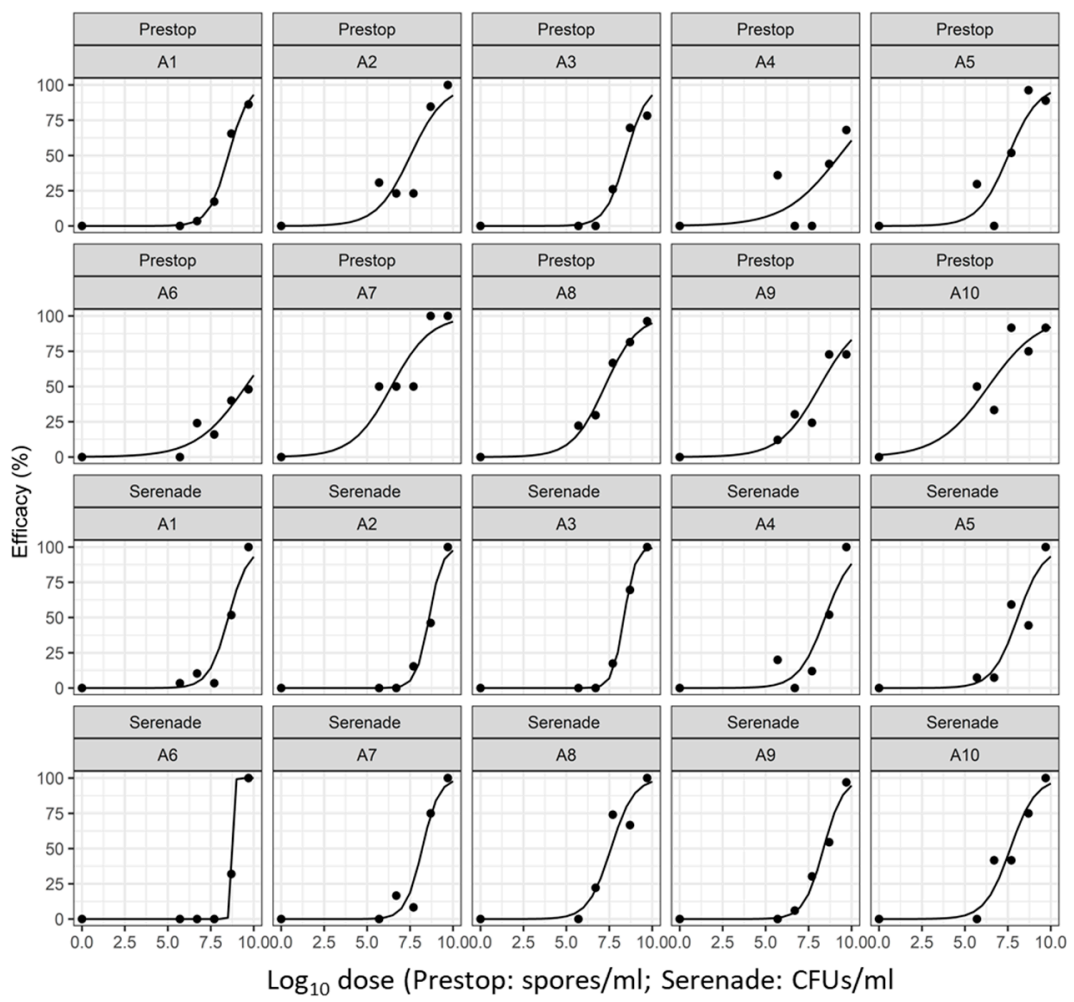

Figure 6. The effect of leaf position on the biocontrol efficacy on L. sativa leaf discs from attached lettuce leaves pre-inoculated with $B$. cinerea and then challenged with two biocontrol products (Prestop and Serenade) at different doses in a glasshouse at $17-22{ }^{\circ} \mathrm{C}$ with a RH range of $60-100 \%$. Curves are fitted logistic models describing the observed dose-response relationships. The exact leaf positions are given in Figure 1.

\section{Discussion}

This study has examined the dose-response relationship between the BCAs B. subtilis and $G$. catenulatum and the control of $B$. cinerea applied initially at a high inoculum both in vitro and in vivo. This has allowed the development of dose-response relationships of the two BCAs against $B$. cinerea on different phylloplane leaf regions.

In vitro studies with both BCAs reduced mycelial growth of the B. cinerea in culture. Interestingly, the formulated BCAs performed better (particularly at low doses) and had higher efficacies than the unformulated microorganisms. This may be partially due to proprietary additives, including stickers and adjuvants, which may improve establishment, especially on phylloplane surfaces. Temperature impacted on the dose-response relationship of the two BCAs. Temperature influences reproduction of both BCAs and the synthesis of lipo-peptides in B. subtilis and hydrolytic enzymes in G. catenulatum. B. subtilis growth becomes marginal at approximately $11^{\circ} \mathrm{C}$, and cold shock proteins, fatty acids and SigB proteins are produced for cellular survival [14], which provides some resilience to environmental stress [15]. Lipo-peptides produced by B. subtilis are involved in antifungal activity, biofilm formation and colonization. Examples include iturin over production in solid-state fermentation at lower temperatures [16], surfactin overproduction at $37^{\circ} \mathrm{C}$ [17] and an increase in mycosubtilin production when temperature decreases from $37^{\circ} \mathrm{C}$ to $25^{\circ} \mathrm{C}$ [18]. G. catenulatum can grow over a wide temperature range $\left(5-34^{\circ} \mathrm{C}\right)$ and survives at up to $42{ }^{\circ} \mathrm{C}$. Optimal growth occurs at $15-25^{\circ} \mathrm{C}$ [4]. Knowledge of the 
ecological windows for the competitiveness of the BCA is important and these windows need to mirror those of the pathogen phase of interest to maximize control [19]. Thus, the effect of interacting conditions of water availability-temperature influences the biomass production of Gliocladium species [20]. This species is able to produce heat shock and cold shock proteins which improve the stress tolerance [21]. Hydrolytic enzymes produced by G. catenulatum are known to be involved in antifungal activity. This BCA species has been shown to produce $\beta$-1,3-glucanase and chitinase [6], and the stability of chitinase was up to $40{ }^{\circ} \mathrm{C}$, contributing to efficacy against B. cinerea [22]. In addition, this species is able to produce a perilipin protein encoded by the Per3 gene which is involved in enhanced mycoparasitic activity at $28^{\circ} \mathrm{C}$ against sclerotia [23]. The production of cold shock proteins in both BCAs, in addition to the synthesis of hydrolytic enzymes and mycoparasitic proteins by G. catenulatum, as well as the production of SigB proteins and lipo-peptides by B. subtilis, probably all contribute to the control of $B$. cinerea colonization of in the phyllosphere of different horticultural crops [24].

This study has shown that these two BCAs prevented B. cinerea conidial activity at high inoculum doses on older lettuce leaves. The maximum mean efficacy of the BCAs on older leaves were obtained at the highest dose applied at $5 \times 10^{9} \mathrm{CFUs} / \mathrm{mL}$, which is much higher than the recommended dose (approximately $10^{7}-10^{8} \mathrm{CFUs} / \mathrm{mL}$ ). For Serenade, this highest dose achieved $92 \%$ and was greater compared to grey mould disease of apples with B. subtilis GA1 (80\%) at $5 \times 10^{8}$ [22] and Botrytis blight of geranium with B. subtilis QST 713 (Serenade max) [23]. Meanwhile, Prestop achieved an efficacy of 77\% (at around $10^{6}$ CFUs / mL) which was greater than that reported for Botrytis blight of geranium with Prestop [25] and similar to B. cinerea stem infection in cucumber and tomato with $G$. catenulatum (>75\%) [26]. The $\mathrm{LD}_{50}$ was around $\log _{10} 8.0$ for Serenade (CFUs $/ \mathrm{mL}$ ) and Prestop (spores $/ \mathrm{mL}$ ) for preventing a high inoculum of $B$. cinerea $\left(\log _{10} 6\right.$ spores $/ \mathrm{mL}$ ) on older lettuce leaves.

In the present study, the dose-response relationship was significantly affected by the exact leaf disc position for both BCAs, particularly in the mid lamina and lateral veins with much lower efficacies. It is possible that the spatial position of the leaf parts affected the BCAs and B. cinerea, including their retention and survival, because of differences in the chemical and physical properties of these phyllosphere surfaces. The presence of symptomless systemic $B$. cinerea infection of lettuce initiated from the roots and migrating into the stem, petiole and leaves suggests that $B$. cinerea populations may reside in the vascular tissue in the midrib area, thus requiring a higher BCA concentration to achieve control. This may also explain the positive infections found in some of the negative controls in the midrib leaf sections [27]. There may also be some morphological differences spatially, which may provide better microclimate conditions for B. cinerea. However, more information is required concerning these aspects and their relative nutrient contents [12]. Other key features, such as cuticles [28], wound and stomatal sites [29,30] and the capacity for producing cell wall degrading enzymes [31], may all influence the level of control of $B$. cinerea obtained with these two BCAs. They may contribute to the observed decline in the control efficacy as well as the shift of the dose-response curve for both BCAs in the apex and midrib regions in contrast to lamina and lateral veins. The competition for space and nutrients [2], lipo-peptide synthesis [1] and induced host resistance [32], especially for $B$. subtilis, and in addition antifungal enzyme production and hyper parasitism $[5,7,23]$ by $G$. catenulatum, probably also contributed to the control of $B$. cinerea on older lettuce leaves.

The present study has drawn attention to the importance of temperature, formulation type and biotic (leaf parts) factors influencing the dose-response relationships, which provide an effective starting point for optimizing the chances of effective biocontrol. Further studies are needed to study the effect of $B$. cinerea disease pressure/inoculum on doseresponse relationships. The approaches developed in this study should help improve the application strategies for these commercially available BCAs.

Temperature influences the reproduction of both BCAs and the synthesis of lipopeptides in B. subtilis and hydrolytic enzymes in G. catenulatum. B. subtilis growth becomes 
marginal at approximately $11^{\circ} \mathrm{C}$, and cold shock proteins, fatty acids and SigB proteins are produced for cellular survival [14], which provides some resilience to environmental stress [13]. Lipo-peptides produced by B. subtilis are involved in antifungal activity, biofilm formation and colonization. Examples include iturin overproduction in solid-state fermentation at lower temperatures [16], surfactin overproduction at $37^{\circ} \mathrm{C}$ [17] and an increase in mycosubtilin production when temperature decreases from $37^{\circ} \mathrm{C}$ to $25^{\circ} \mathrm{C}$ [18]. G. catenulatum can grow over a wide temperature range $\left(5-34^{\circ} \mathrm{C}\right)$ and survives at up to $42{ }^{\circ} \mathrm{C}$. Optimal growth occurs at $15-25{ }^{\circ} \mathrm{C}$ [4]. Knowledge of the ecological windows for the competitiveness of the $\mathrm{BCA}$ is important and these windows need to mirror those of the pathogen phase of interest to maximize control [19]. Thus, the effect of interacting conditions of water availability-temperature influences the biomass production of Gliocladium species [20]. This species is able to produce heat shock and cold shock proteins, which improves the stress tolerance [21]. Hydrolytic enzymes produced by G. catenulatum are known to be involved in antifungal activity. This BCA species has been shown to produce $\beta$-1,3-glucanase and chitinase [6], and chitinase was stable at up to $40^{\circ} \mathrm{C}$, contributing to efficacy against $B$. cinerea [22]. In addition, this species is able to produce a perilipin protein encoded by the Per3 gene, which is involved in enhanced mycoparasitic activity at $28^{\circ} \mathrm{C}$ against sclerotia [23]. The production of cold shock proteins in both BCAs, in addition to the synthesis of hydrolytic enzymes and mycoparasitic proteins by G. catenulatum, as well as the production of SigB proteins and lipo-peptides by B. subtilis, probably all contribute to the control of $B$. cinerea colonization in the phyllosphere of different horticultural crops.

\section{Conclusions}

This study has shown that both BCAs inhibit the colonization of $B$. cinerea inoculum in vitro over a range of temperatures, with formulated versions having an advantage in the control efficacy. Dose-response curves of both BCAS against $B$. cinerea were developed and shown to be influenced by temperature, formulation and leaf part. In situ studies on lettuce leaves, especially the spatial variability of biocontrol related to leaf positions, showed the importance of taking the phyllosphere morphology into account when delivering BCAs to such surfaces to control this important pathogen.

Author Contributions: G.T. was a PhD student who executed the research work and prepared the first draft; X.X. and N.M. devised the project and were the PhD supervisors, corrected the drafts, provided additional statistical analyses and revised the final submitted version of the manuscript; P.B. carried out the statistical analyses of the data sets. All authors have read and agreed to the published version of the manuscript.

Funding: This research received no external funding.

Institutional Review Board Statement: Not applicable.

Data Availability Statement: All the data sets for statistical analyses have been deposited with the corresponding authors, X. Xu and N. Magan, and are available from NIAB-EMR or Cranfield University.

Acknowledgments: G.T. is grateful to the AHDB for financial support for the PhD project (Project number CP140).

Conflicts of Interest: The authors declare no conflict of interest.

\section{References}

1. Ongena, M.; Jourdan, E.; Adam, A.; Paquot, M.; Brans, A.; Joris, B.; Arpigny, J.L.; Thonart, P. Surfactin and fengycin lipopeptides of Bacillus subtilis as elicitors of induced systemic resistance in plants. Environ. Microbiol. 2007, 9, 1084-1090. [CrossRef]

2. Hibbing, M.E.; Fuqua, C.; Parsek, M.R.; Peterson, S.B. Bacterial competition: Surviving and thriving in the microbial jungle. Nat. Rev. Microbiol. 2010, 8, 15. [CrossRef] [PubMed]

3. Fischer, S.; Príncipe, A.; Alvarez, F.; Cordero, P.; Castro, M.; Godino, A.; Jofré, E.; Mori, G. Fighting plant diseases through the application of Bacillus and Pseudomonas strains. In Symbiotic Endophytes; Springer: Berlin/Heidelberg, Germany, 2013.

4. Helyer, N.; Cattlin, N.D.; Brown, K.C. Biological Control in Plant Protection: A Colour Handbook; CRC Press: Boca Raton, FL, USA, 2014. 
5. Huang, H. Gliocladium catenulatum: Hyperparasite of Sclerotinia sclerotiorum and Fusarium species. Can. J. Bot. 1978, 56, 2243-2246. [CrossRef]

6. McQuilken, M.; Gemmell, J.; Lahdenpera, M. Gliocladium catenulatum as a potential biological control agent of damping-off in bedding plants. J. Phytopathol. 2001, 149, 171-178. [CrossRef]

7. Lahdenpera, M.; Korteniemi, M. Application of microbial fungicides on horticultural crops: A case study with Gliocladium catenulatum J1446. In EBA 2005, Proceedings of the 1st International Conference on Plant Microbe Interactions: Endophytes and Biocontrol Agents; Saariselkä, Finland, 18-22 April 2005, Sorvari, S., Toldi, O., Eds.; BioBien Innovations: Kaarina, Finland, 2005.

8. Chatterton, S.; Jayaraman, J.; Punja, Z.K. Colonization of cucumber plants by the biocontrol fungus Clonostachys rosea f. catenulata. Biol. Control 2008, 46, 267-278. [CrossRef]

9. Sherf, A.F.; MacNnab, A.A. Vegetable Diseases and Their Control; John Wiley \& Sons: Hoboken, NJ, USA, 1986.

10. Shim, C.K.; Kim, M.J.; Kim, Y.K.; Jee, H.J. Evaluation of lettuce germplasm resistance to gray mold disease for organic cultivations. Plant Pathol. J. 2014, 30, 90. [CrossRef]

11. Montesinos, E.; Bonaterra, A. Dose-response models in biological control of plant pathogens: An empirical verification. Phytopathology 1996, 86, 464-472. [CrossRef]

12. Mirik, M.; Öksel, C. Plant pathogenic bacteria control through foliar application. In Sustainable Approaches to Controlling Plant Pathogenic Bacteria; CRC Press: Boca Raton, FL, USA, 2006; p. 333.

13. Landa, B.B.; Hervás, A.; Bettiol, W.; Jiménez-Díaz, R.M. Antagonistic activity of bacteria from the chickpea rhizosphere against Fusarium oxysporum f. sp. Ciceris. Phytoparasitica 1997, 25, 305-318. [CrossRef]

14. Price, C.W. Protective function and regulation of the general stress response in Bacillus subtilis and related gram-positive bacteria. In Bacterial Stress Responses; Storz, G., Hengge-Aronis, R., Eds.; American Society for Microbiology: Washington, DC, USA, 2000; pp. 179-197.

15. Bernhardt, J.; Völker, U.; Völker, A.; Antelmann, H.; Schmid, R.; Mach, H.; Hecker, M. Specific and general stress proteins in Bacillus subtilis-a two-dimensional protein electrophoresis study. Microbiology 1997, 143, 999-1017. [CrossRef] [PubMed]

16. Ohno, A.; Ano, T.; Shoda, M. Effect of temperature on production of lipopeptide antibiotics, iturin A and surfactin by a dual producer, Bacillus subtilis RB14, in solid-state fermentation. J. Fermen. Bioeng. 1995, 80, 517-519. [CrossRef]

17. Akpa, E.; Jacques, P.; Wathelet, B.; Paquot, M.; Fuchs, R.; Budzikiewicz, H.; Thonart, P. Influence of culture conditions on lipopeptide production by Bacillus subtilis. Appl. Biochem. Biotechnol. 2001, 91, 551-561. [CrossRef]

18. Fickers, P.; Leclère, V.; Guez, J.-S.; Béchet, M.; Coucheney, F.O.; Joris, B.; Jacques, P. Temperature dependence of mycosubtilin homologue production in Bacillus subtilis ATCC6633. Res. Microbiol. 2008, 159, 449-457. [CrossRef]

19. Magan, N. Importance of ecological windows for efficacy of biocontrol agents. In How Research Can Stimulate the Development of Commercial Biological Control against Plant Diseases; Progress in Biocontrol; De Cal, A., Melgarejo, P., Magan, N., Eds.; Springer: Berlin/Heidelberg, Germany, 2020; Chapter 1. [CrossRef]

20. Harman, G.E.; Kubicek, C.P. Trichoderma and Gliocladium. Volume 1: Basic Biology, Taxonomy and Genetics; CRC Press: Boca Raton, FL, USA, 1998.

21. Tiwari, S.; Thakur, R.; Shankar, J. Role of heat-shock proteins in cellular function and in the biology of fungi. Biotechnol. Res. Int. 2015, 2015, 132635. [CrossRef]

22. Ma, G.-Z.; Gao, H.-L.; Zhang, Y.-H.; Li, S.-D.; Xie, B.-Y.; Wu, S.-J. Purification and characterization of chitinase from Gliocladium catenulatum strain HL-1-1. Afr. J. Microbiol. Res. 2012, 6, 4377-4383.

23. Sun, Z.-B.; Li, S.-D.; Zhong, Z.-M.; Sun, M.-H. A perilipin gene from Clonostachys rosea f. catenulata HL-1-1 is related to sclerotial parasitism. Int. J. Mol. Sci. 2015, 16, 5347-5362. [CrossRef]

24. Toure, Y.; Ongena, M.; Jacques, P.; Guiro, A.; Thonart, P. Role of lipopeptides produced by Bacillus subtilis GA1 in the reduction of grey mould disease caused by Botrytis cinerea on apple. J. Appl. Microbiol. 2004, 96, 1151-1160. [CrossRef]

25. Elmhirst, J.F.; Haselhan, C.; Punja, Z.K. Evaluation of biological control agents for control of Botrytis blight of geranium and powdery mildew of rose. Can. J. Plant Pathol. 2011, 33, 499-505. [CrossRef]

26. Dik, A.J.; Koning, G.; Köhl, J. Evaluation of microbial antagonists for biological control of Botrytis cinerea stem infection in cucumber and tomato. Eur. J. Plant Pathol. 1999, 105, 115-122. [CrossRef]

27. Sowley, E.N.; Dewey, F.M.; Shaw, M.W. Persistent, symptomless, systemic, and seed-borne infection of lettuce by Botrytis cinerea. Eur. J. Plant Pathol. 2010, 126, 61-71. [CrossRef]

28. Serrano, M.; Coluccia, F.; Torres, M.; L'haridon, F.; Métraux, J.-P. The cuticle and plant defense to pathogens. Front. Plant Sci. 2015, 5, 274. [CrossRef] [PubMed]

29. Dugan, F.; Blake, G.M. Penetration and infection of western larch seedlings by Botrytis cinerea. Can. J. Bot. 1989, 67, 2596-2599. [CrossRef]

30. Faulkner, C.; Robatzek, S. Plants and pathogens: Putting infection strategies and defence mechanisms on the map. Curr. Opin. Plant Biol. 2012, 15, 699-707. [CrossRef] [PubMed]

31. Kubicek, C.P.; Starr, T.L.; Glass, N.L. Plant cell wall-degrading enzymes and their secretion in plant-pathogenic fungi. Ann. Rev. Phytopathol. 2014, 52, 427-451. [CrossRef]

32. Gond, S.K.; Bergen, M.S.; Torres, M.N.S.; White, J.F., Jr. Endophytic Bacillus spp. produce antifungal lipopeptides and induce host defence gene expression in maize. Microbiol. Res. 2015, 172, 79-87. [CrossRef] 